\title{
YIELD, IRRIGATION PRODUCTION EFFICIENCY AND ECONOMIC RETURNS OF BROCCOLI UNDER VARIABLE DRIP IRRIGATION AND LATERAL SPACING
}

\author{
J. L.G. Kumar ${ }^{1}$, M. Imtiyaz ${ }^{2}$ \\ ${ }^{1}$ Department of Water Resources Engineering, Faculty of Engineering, \\ Bahir Dar University, Bahir Dar, Ethiopia. \\ ${ }^{2}$ Department of Soil Water Land Engineering and Management \\ Allahabad Agricultural Institute-Deemed University, Allahabad-India
}

\begin{abstract}
Field studies were carried out for 2 years (2001 - 2003) on clay loam soil to determine the effect of variable irrigation (50, 100, 150 and $200 \%$ of pan evaporation replenishment) and lateral spacing (0.5 and 1.0m) on yield, irrigation production efficiency and economic return of broccoli (Brassica oleracea). The irrigation was applied when sum of daily pan evaporation (5 years) from United States Weather Bureau (USWB) Class $A$ open pan reached approximately up to $16.3 \mathrm{~mm}$ after accounting for rainfall. The crop was irrigated by drip irrigation system. Irrigation at $150 \%$ of pan evaporation replenishment and $0.5 \mathrm{~m}$ lateral spacing resulted in higher marketable yield of primary and secondary flowers. A further increase in irrigation amount resulted from $200 \%$ pan evaporation replenishment reduced marketable flower yield significantly. The higher irrigation production efficiency was recorded at 50\% of pan evaporation replenishment and $0.5 m$ lateral spacing and it decreased significantly with an increase in irrigation amount and lateral spacing Irrigation at $150 \%$ of pan evaporation replenishment resulted in a higher net return and benefit-cost ratio. The lateral spacing of $1.0 \mathrm{~m}$ gave higher net return and benefit-cost ratio as compared to lateral spacing of $0.5 \mathrm{~m}$. The seasonal water applied and marketable flower yield, gross return, net return and benefit-cost ratio exhibited quadratic relationship which can be used for optimising economic return of broccoli under variable irrigation and lateral spacing. The results revealed that drip irrigation system is profitable for broccoli production inspite of high initial investment.
\end{abstract}

Keywords:Drip Irrigation, Variable irrigation, Lateral spacing, yield, economic return, and broccoli

\section{INTRODUCTION}

Water resource in the northern plain region of India is becoming scarce and expensive to exploit due to erratic rainfall and over-exploitation of surface and subsurface water resources. Due to fast economic growth and urbanisation, the competition of limited water resources for agriculture, domestic and industrial needs is increasing considerably. The present irrigation management practices in this region results in heavy 
conveyance and water application losses, which in turn leads to water logging, salinity and ground water contamination. For sustainable crop production to feed the ever-growing population in India, it is essential to develop efficient and economically viable irrigation management practices in order to irrigate more land area with existing limited water resources.

Irrigation scheduling is a critical management input to ensure adequate soil moisture for optimum plant growth, yield, quality, water use efficiency and economic returns. Irrigation scheduling which determines the timing and amount of irrigation is governed by many factors but the microclimate plays the most important role. Therefore, it is essential to develop irrigation scheduling techniques under prevailing climatic conditions. For the last 2-3 decades, numerous studies have been carried out on the development and evaluation of irrigation scheduling techniques under a wide range of agro-climatic conditions (Jensen et al., 1970; Hiller and Howell 1973; Steele et al. 1997; Mahdi et al. 1977; Misra and Pant 1981; Imtiyaz and Shiromani 1990; Wanjura et al. 1990; Imtiyaz et al. 2000 d). The meteorologically based irrigation scheduling approach such as pan evaporation replenishment, cumulative pan evaporation and the ratio between irrigation water and cumulative pan evaporation was used extensively due to its simplicity, data availability and higher degree of adoptability (Prihar et al. 1974; Singh 1987; Singh and Mohan 1994; Singh et al. 1997; Imtiyaz et al. 2000b, c). Imtiyaz et al. 2000a reported the higher marketable yield, irrigation production efficiency and net return of broccoli with irrigation at $80 \%$ of pan evaporation replenishment under the climatic condition of north western region of Botswana.

Surface irrigation is the most common method for vegetable, fruit and flower crops in this region. The overall efficiencies of surface irrigation methods are considerably lower as compared to drip, micro-sprinkler and overhead sprinkler irrigation. Due to increasing water scarcity, the
Government of India is encouraging farmers to adopt efficient irrigation methods and, thereby, to feed the ever-growing population. The Drip irrigation with its ability for small but frequent water application have been found superior in terms of water economy, yield and water use/ irrigation production efficiency (Theodor 1980; Pruitt et al. 1984; Srivastava et al. 1994; Hanson et al. 1997; Fekadu and Teshome 1998; Imtiyaz et al. 2000d). The initial investment of drip irrigation is considerably higher as compared to conventional surface irrigation methods. The cost of laterals and emitters are the major factors influencing initial investment. Therefore, it is necessary to develop strategies in order to reduce the cost of lateral network and emitters per hectare to make drip irrigation affordable to the farming community in this region. Devitt and Miller (1988) investigated several lateral spacings on two soils for Bermuda grass concluding that $0.6 \mathrm{~m}$ spacing was acceptable for a sandy loam, but a closer spacing would be required for clay. Camp et al. (1997) reported higher cotton yields with every row drip line placement compared with alternate row placement. Lamm et al. (1995) used alternate row spacing for corn and reported water savings approaching $25 \%$. However, more specific information is required for specific soil-crop-climatic combinations.

Broccoli is an important vegetable crop but the importance of this vegetable is limited in India due to the lack of information on irrigation management, yield potential and economic returns. Broccoli is known as the crown jewel of nutrition because it is rich in vitamins $\mathrm{A}, \mathrm{B}, \mathrm{B}_{2}$ and $\mathrm{C}$. Drip irrigation is popular in several agro-climatic zones in India except in the state of Uttar Pradesh mainly due to the lack of information on irrigation scheduling techniques and economic viability of the system. Therefore, the objective of the present study was to investigate the effect of variable irrigation and lateral spacing of drip irrigation on marketable yield, irrigation production efficiency and economic return of broccoli in a semi-arid climate.

112 Journal of Science and Technology, Volume 27 no. 2, August, 2007 


\section{MATERIALS AND METHODS}

Field experiments were conducted at the Irrigation Research Farm of Allahabad Agricultural Institute - Deemed University, Allahabad, India $\left(25^{\circ} 27^{\prime} \mathrm{N}, 81^{\circ} \mathrm{E}, 98 \mathrm{~m}\right.$ above mean sea level) for two consecutive winter seasons $(2001-2003)$ in order to examine the effect of variable irrigation and lateral spacing on yield, irrigation production efficiency and economic return of broccoli. The climate in this part of the country has been classified as semi-arid. The climatic parameters during the crop growing periods are summarized in Table 1. The soil of the experimental field was fertile clay loam (35.5\% sand, $25.8 \%$ silt and $36.6 \%$ clay) with average bulk density of $1.31 \mathrm{~g} /$ $\mathrm{cm}^{3}$. The soil moisture content at field capacity ($1 / 3$ bar) and wilting point (-15 bar) were $19.5 \%$ and $9.1 \%$ on dry weight basis. The plant available soil moisture was $136 \mathrm{~mm} / \mathrm{m}$.
The experiments were laid out in a two-factor complete randomised block design with three replications. The area of each experimental plot was $15 \mathrm{~m}^{2}$. A buffer zone spacing of $1.0 \mathrm{~m}$ was provided between the plots. Prior to transplanting, the experimental field of broccoli received $68 \mathrm{~kg} / \mathrm{ha} \mathrm{N}, 94.3 \mathrm{~kg} / \mathrm{ha} \mathrm{P}_{2} \mathrm{O}_{5}$ and $62.5 \mathrm{~kg} / \mathrm{ha} \mathrm{K}_{2} \mathrm{O}$. The experimental plot of broccoli received 66 $\mathrm{kg} /$ ha $\mathrm{N}$ after 5 and 7 weeks of transplanting. Broccoli (hybrid var. Fiesta) seed was sown on 26 October 2001 and 30 October 2002 in the nursery at a depth of $0.05 \mathrm{~m}$ with a spacing of 10 $\mathrm{cm}$ between the rows. Broccoli seedlings were transplanted on 7 December in 2001 and 10 December in 2002 at a plant spacing of $0.5 \mathrm{~m} \mathrm{x}$ $0.5 \mathrm{~m}$.

The experiment consisted of four irrigation levels, i.e. the amount of water in different treat-

Table 1: Yield and irrigation production efficiency of broccoli as influenced by irrigation levels and lateral spacing

\begin{tabular}{|c|c|c|c|c|c|c|c|c|}
\hline \multirow{3}{*}{$\begin{array}{c}\text { Treatment (Pan } \\
\text { evaporation } \\
\text { replenishment, \%) }\end{array}$} & \multicolumn{6}{|c|}{ Mean marketable yield (t/ha) } & \multirow{2}{*}{\multicolumn{2}{|c|}{$\begin{array}{c}\text { Mean irrigation } \\
\text { production efficiency } \\
\left(\mathbf{k g} / \mathbf{m}^{3}\right)\end{array}$}} \\
\hline & \multicolumn{2}{|c|}{$\begin{array}{l}\text { Primary flowers, } \\
\text { t/ha }\end{array}$} & \multicolumn{2}{|c|}{$\begin{array}{c}\text { Secondary } \\
\text { flowers, } t / h a\end{array}$} & \multicolumn{2}{|c|}{$\begin{array}{l}\text { Total (primary }+ \\
\text { Secondary), t/ha }\end{array}$} & & \\
\hline & 2002 & 2003 & 2002 & 2003 & 2002 & 2003 & 2002 & 2003 \\
\hline 50 & 17.53 & 18.20 & 1.45 & 1.55 & 18.98 & 19.55 & 16.62 & 16.80 \\
\hline 100 & 22.85 & 23.75 & 2.70 & 3.00 & 25.30 & 26.50 & 12.30 & 12.86 \\
\hline 150 & 26.97 & 28.25 & 4.85 & 5.00 & 31.80 & 33.05 & 10.72 & 11.06 \\
\hline 200 & 24.57 & 26.00 & 3.55 & 3.60 & 28.10 & 29.00 & 7.22 & 7.51 \\
\hline $\operatorname{LSD}(0.05)$ & 0.86 & 0.98 & 0.18 & 0.26 & 0.90 & 0.75 & 0.59 & 0.48 \\
\hline Lateral spacing, $\mathbf{m}$ & & & & & & & & \\
\hline 0.5 & 23.78 & 24.67 & 3.41 & 3.52 & 27.18 & 28.00 & 12.42 & 12.75 \\
\hline 1.0 & 22.18 & 23.42 & 2.88 & 3.05 & 24.94 & 26.05 & 11.01 & 11.45 \\
\hline $\operatorname{LSD}(0.05)$ & 0.61 & 0.75 & 0.12 & 0.19 & 0.64 & 0.56 & 0.42 & 0.48 \\
\hline $\begin{array}{c}\text { Interaction LSD } \\
(0.05)\end{array}$ & 1.21 & 1.02 & 0.25 & 0.29 & 1.27 & 1.38 & 0.77 & 0.67 \\
\hline
\end{tabular}


ments was 50,100, 150 and 200\% USWB class A pan evaporation replenishment and two lateral spacings i.e. $0.5 \mathrm{~m}$ (lateral at every row) and $1.0 \mathrm{~m}$ (lateral at every alternate rows). The pan was located at a Agro-meteorological Station adjacent to the experimental site with a moderate grass cover. Crop was irrigated when the sum of the daily mean (5 years) of pan evaporation reached approximately a pre-determined value of $16.3 \mathrm{~mm}$ (rooting depth in $\mathrm{m} \times$ plant available soil moisture in $\mathrm{mm} / \mathrm{m} \times$ readily available soil moisture in fraction). The crops were irrigated by the surface drip irrigation method. The drip irrigation system was designed and installed to meet the objectives of the experiment. The irrigation water was pumped directly from tube-well to the concrete tank and thereafter it was pumped from the tank to the drip irrigation system. Screen filter was installed on the main line to minimise dripper blockage. The $50 \mathrm{~mm}$ diameter PVC pipes and $12 \mathrm{~mm}$ diameter Low Density Polyethylene pipes were used for the sub-main and laterals respectively. The laterals were laid on each row at $0.5 \mathrm{~m}$ spacing) as well as in alternate rows at $1.0 \mathrm{~m}$ spacing). The broccoli was watered by 4 $\ell / h$ non-pressure compensated on-line drippers. The spacing between drippers was $0.5 \mathrm{~m}$. The experimental plot was connected by a control valve in order to deliver the desired amount of water. The sub-main was connected to a water meter and control valve. During the first 2 weeks, the crops were irrigated daily at $75 \%$ of pan evaporation losses in order to establish newly planted seeds. Standard cultural practices were adopted during the crop-growing season. Crop was harvested from $18-28$ March in both years, depending upon the maturity of primary and secondary flowers. Crop yield was obtained upon the weight of the flowers and it was measured in terms of tones/ha. Further irrigation production efficiency was obtained by the formula,

Irrigation Production Efficiency, $\mathrm{Kg} / \mathrm{m}^{3}$

$=\frac{\text { Marketable Yield, } \mathrm{Kg} / \mathrm{ha}}{\text { Total Water Applied, } \mathrm{m}^{3} / \mathrm{ha}}$
In order to assess the economic viability of the drip irrigation system under variable irrigation and lateral spacings, both fixed and operating costs were considered. Total cost, gross return and net return were estimated on the following assumptions:

Salvage value of the components $=0$

Useful life of tube-well, pump, motor and pump house $=25$ years

Useful life of drip irrigation system $=7$ years

Useful life of weeding and spraying equipments

$=7$ years

Interest rate

$=14 \%$ p.a.

Repair and maintenance

$=7.5 \%$

Number of crops per year

$=2$

The fixed cost was calculated, including water development (tube-well, pump, motor, pumphouse and other accessories) and drip irrigation system (low density polyethylene pipe for main, sub main and laterals, filters, fertiliser unit, pressure gauges, control valves, water meter, drippers and other accessories). The annual fixed cost for water development and irrigation system under variable irrigation and lateral spacing was calculated separately by the following approach (James and Lee, 1971):

$$
C R F=\frac{i(1+i)^{n}}{(1+i)^{n}-1}
$$

Where,

$$
\begin{aligned}
\mathrm{CRF} & =\text { Capital recovery factor } \\
\mathrm{i} & =\text { interest rate (fraction) } \\
\mathrm{n} & =\text { Useful life of components (years) }
\end{aligned}
$$

Annual fixed cost $/$ ha $=\mathrm{CRF} x$ fixed cost $/$ ha

Fixed cost $/$ ha $/$ season $=\frac{\text { Annual fixed cost } / \text { ha }}{2}$

114 Journal of Science and Technology, Volume 27 no. 2, August, 2007 
The operating cost including labour (system installation, planting, irrigation, weeding, cultivation, fertiliser application, spraying and harvesting, etc.), land preparation, seeds, fertilisers, chemicals, water pumping and repair and maintenance was calculated. The gross revenue for different irrigation levels and lateral spacing was calculated, taking into consideration the marketable yield and current wholesale price of broccoli. Subsequently, the net returns under different irrigation levels and lateral spacings were calculated considering the total cost of production and gross revenue.

The benefit-cost ratio $(\mathrm{B} / \mathrm{C})$ under variable irrigation items and lateral spacing was calculated as follows:

$\mathrm{B} / \mathrm{C}=\frac{\text { Gross revenue }(\mathrm{Rs} / \mathrm{ha})}{\text { Total cost of production }(\mathrm{Rs} / \mathrm{ha})}$

\section{RESULTS AND DISCUSSION}

Yield and irrigation production efficiency

In both seasons (2002 and 2003), irrigation levels significantly influenced the marketable yield of broccoli (Table 1). In both the years, the highest marketable yield of primary $(26.97-28.25 \mathrm{t} / \mathrm{ha})$ and secondary $(4.85-5.00 \mathrm{t} / \mathrm{ha})$ flowers was observed when irrigation during the crop growing season was applied at $150 \%$ of pan evaporation replenishment mainly due to higher mean flower weight. A further increase in the amount of irrigation resulted from $200 \%$ of pan evaporation replenishment reducing the marketable yield of primary and secondary flowers due to significant reduction in mean flower weight. The lower marketable yield for 50 and $100 \%$ of pan evaporation replenishment resulted from a significant decrease in flower weight. Lateral spacing had significant effect on mean flower weight and marketable yield of primary and secondary flowers (Table 2). The irrigation production efficiency of broccoli was influenced by irrigation levels and lateral spacing. In both years the highest irrigation production efficiency (16.62 $16.80 \mathrm{~kg} / \mathrm{m}^{3}$ ) was recorded at $50 \%$ pan evaporation replenishment. Irrigation at $200 \%$ of pan evaporation replenishment resulted in significantly minimum irrigation production efficiency $\left(7.22-7.51 \mathrm{~kg} / \mathrm{m}^{3}\right)$ because it increased the seasonal water application but decreased the marketable flower yield. The significantly higher irrigation production efficiency $\left(12.42-12.75 \mathrm{~kg} / \mathrm{m}^{3}\right)$

Table 2: Economic analysis for broccoli under different irrigation schedules and lateral spacing (average data of 2 years).

\begin{tabular}{cccccccccc}
\hline & \multicolumn{3}{c}{$\mathbf{0 . 5 m}$ lateral spacing $\left(\mathbf{L S}_{1}\right)$} & \multicolumn{5}{c}{$\mathbf{1 . 0 m}$ lateral spacing $\left(\mathbf{L S}_{2}\right)$} \\
$\begin{array}{c}\text { Treatment } \\
\text { (Pan evapo- } \\
\text { ration replen- } \\
\text { ishment, \%) }\end{array}$ & $\begin{array}{c}\text { Total cost of } \\
\text { production }\end{array}$ & $\begin{array}{c}\text { Gross } \\
\text { Return }\end{array}$ & Net Return & $\begin{array}{c}\text { Benefit } \\
\text { cost ratio }\end{array}$ & $\begin{array}{c}\text { Total cost of } \\
\text { production }\end{array}$ & $\begin{array}{c}\text { Gross } \\
\text { Return }\end{array}$ & $\begin{array}{c}\text { Net Re- } \\
\text { turn }\end{array}$ & $\begin{array}{c}\text { Benefit cost } \\
\text { ratio }\end{array}$ \\
\hline 50 & 1935 & 5827 & 3893 & 3.00 & 1598 & 4691 & 3093 & 2.93 \\
100 & 1955 & 7423 & 5468 & 3.78 & 1618 & 6718 & 5099 & 4.14 \\
150 & 1975 & 8986 & 7011 & 4.54 & 1639 & 8723 & 7084 & 5.35 \\
200 & 1996 & 7882 & 5886 & 3.93 & 1659 & 7705 & 6046 & 4.65 \\
\hline
\end{tabular}

Note: The price of broccoli is taken as US\$ 0.27 (Approximately Rs or INR. 12/- kg) 1 US\$ = Approximately Rs.44 
was obtained when laterals were provided for every row of the crop. In all the irrigation levels, the maximum irrigation production efficiency was obtained when laterals were provided in every crop rows as compared with laterals at alternate rows (Table 2). The higher marketable flower yield and flower weight was recorded at $150 \%$ of pan evaporation replenishment, whereas irrigation at $50 \%$ of pan evaporation replenishment gave the higher irrigation production efficiency when laterals were provided at $0.5 \mathrm{~m}$ spacing. Similar trends were reported by many researchers elsewhere for other crops, irrigation regimes and climatic conditions (Phene and Sanders 1976; Devitt and Miller 1988; Singh and Mohan 1994; Imtiyaz et al. 2000c, 2002).

\section{Economic Returns}

The total cost of production and net return of broccoli under different irrigation levels and lateral spacings are presented in Table 2. The total cost of production (fixed and operating costs) increased slightly with an increase in pan evaporation replenishment (irrigation levels) because the pumping cost was insignificant as compared to the total cost of production. The total cost of production was considerably higher for $0.5 \mathrm{~m}$ lateral spacing as compared to $1.0 \mathrm{~m}$ lateral spacing due to higher fixed cost resulting from considerably higher number of drippers/ha and lateral length. The repair and maintenance cost for $0.5 \mathrm{~m}$ and $1.0 \mathrm{~m}$ lateral spacing contributed $2.86 \%$ and $2.02 \%$ respectively to the total cost of production. The labour cost to perform major farm activities for 0.5 and $1.0 \mathrm{~m}$ lateral spacing contributed $27.80 \%$ and $33.48 \%$ respectively to the total cost of production. The cost of land preparation, land rent, seed, fertilizers and chemicals for $0.5 \mathrm{~m}$ lateral spacing contributed 26.78 and $32.25 \%$ respectively to the total cost of production. The net return of broccoli for both $0.5 \mathrm{~m}$ and $1.0 \mathrm{~m}$ lateral spacing increased sharply from 50 to $100 \%$ of pan evaporation replenishment due to sharp increase in marketable flower yield. A further increase in irrigation level resulted from
$200 \%$ of pan evaporation replenishment decreasing the net return because it increased the total cost of production, but decreased the gross return. The maximum net return for $0.5 \mathrm{~m}$ and $1.0 \mathrm{~m}$ lateral spacing was US\$ 7011/ha and US\$ 7084/ ha respectively (Table 2 ). The benefit cost ratio $(\mathrm{B} / \mathrm{C})$, which indicates gross revenue per unit investment was also influenced by irrigation level and lateral spacing. The irrigation at $150 \%$ of pan evaporation replenishment gave the maximum benefit cost ratio for $0.5 \mathrm{~m}(4.54)$ and $1.0 \mathrm{~m}$ (5.35) lateral spacing because increase in gross return was higher as compared to total cost of production. However, the benefit cost ratio for $1.0 \mathrm{~m}$ lateral spacing at 100,150 and $200 \%$ of pan evaporation replenishment was higher than $0.5 \mathrm{~m}$ lateral spacing mainly due to higher reduction in total cost of production as compared with gross return (Table 2). The results revealed that under different lateral spacing irrigation at $150 \%$ of pan evaporation replenishment gave the maximum gross return, net return and benefit cost ratio. The overall results under different lateral spacings revealed that irrigation at $150 \%$ of pan evaporation replenishment gave the maximum gross return, net return and benefit cost ratio. Similar results were reported by some researchers under wide variety of irrigation systems and regimes, soil crop and climatic conditions (Srivastava et al. 1994; Singh et al. 1997; Tiwari and Reddy 1997; Imtiyaz et al. 2000a,b, d, e and 2002.

Relationship between water applied, yield, gross return, net return and benefit cost ratio The relationship between seasonal water applied versus marketable flower yield, gross return, net return and $\mathrm{B} / \mathrm{C}$ ratio are shown in Fig. 1, 2, 3 and 4. The seasonal water applied to broccoli ranged from $114-387$ and $116-386 \mathrm{~mm}$ whereas marketable yield for $0.5 \mathrm{~m}$ and $1.0 \mathrm{~m}$ lateral spacings ranged from $18.98-31.80$ and $19.55-29.00 \mathrm{t} /$ ha respectively. The seasonal water applied to broccoli for $0.5 \mathrm{~m}\left(\mathrm{R}^{2}=0.9387\right)$ and $1.0 \mathrm{~m}\left(\mathrm{R}^{2}=\right.$ 0.9460) lateral spacing exhibited strong quadratic relationship. The marketable yield of broccoli

116 Journal of Science and Technology, Volume 27 no. 2, August, 2007 


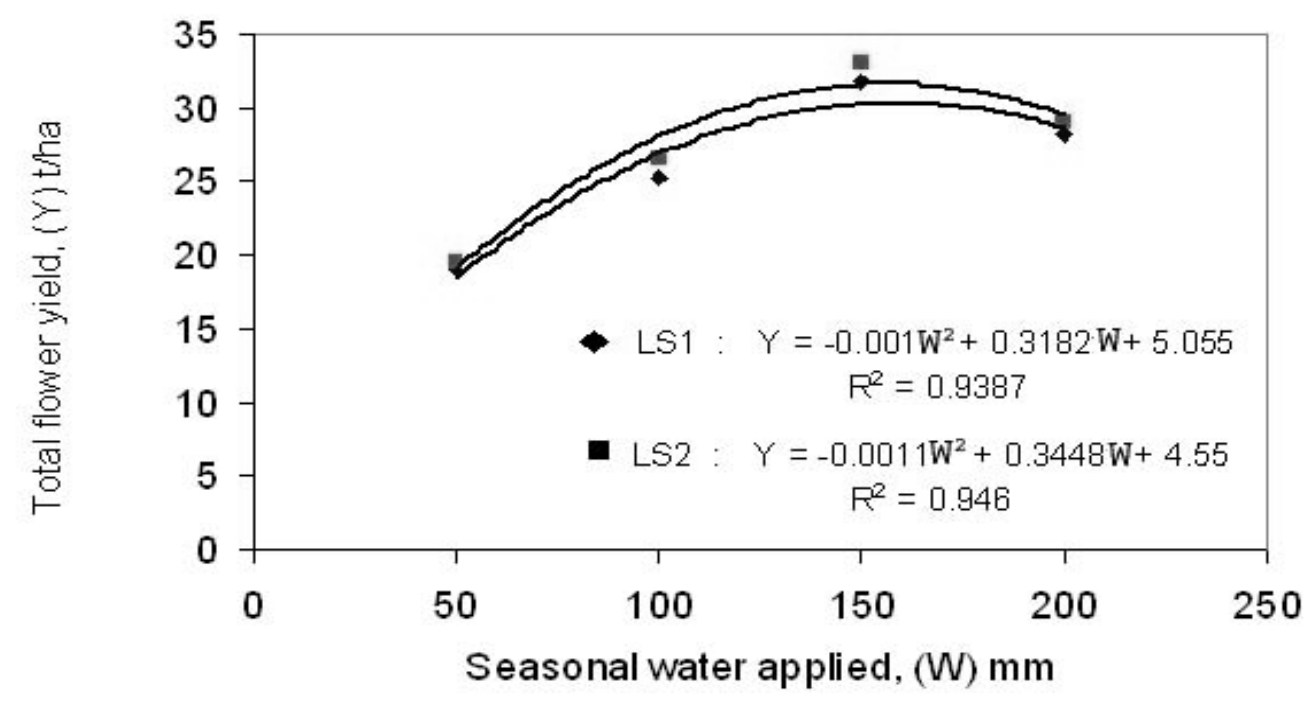

Fig. 1: Relationship between seasonal water applied and total flower yield of Broccoli for $0.5 \mathrm{~m}$ and $1.0 \mathrm{~m}$ lateral spacing

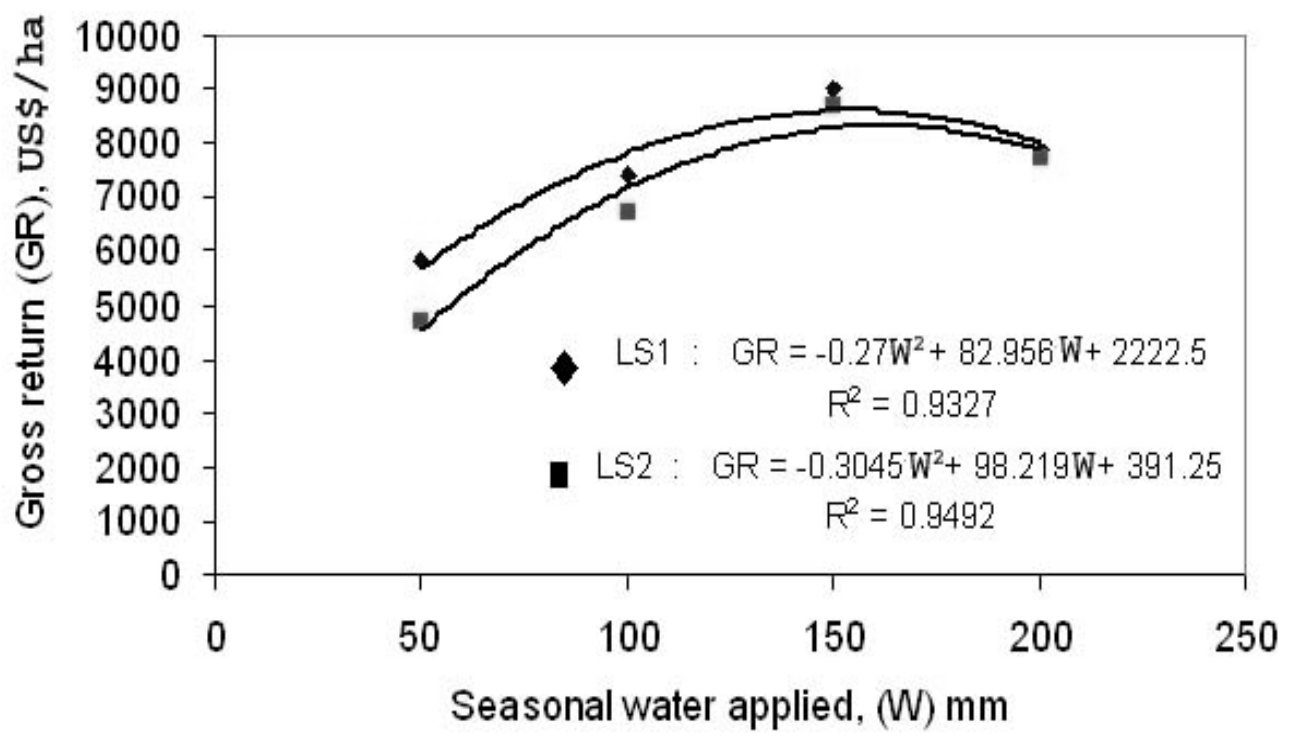

Fig. 2: Relationship between Seasonal water applied and gross return of Broccoli for $0.5 \mathrm{~m}$ and $1.0 \mathrm{~m}$ lateral spacing 


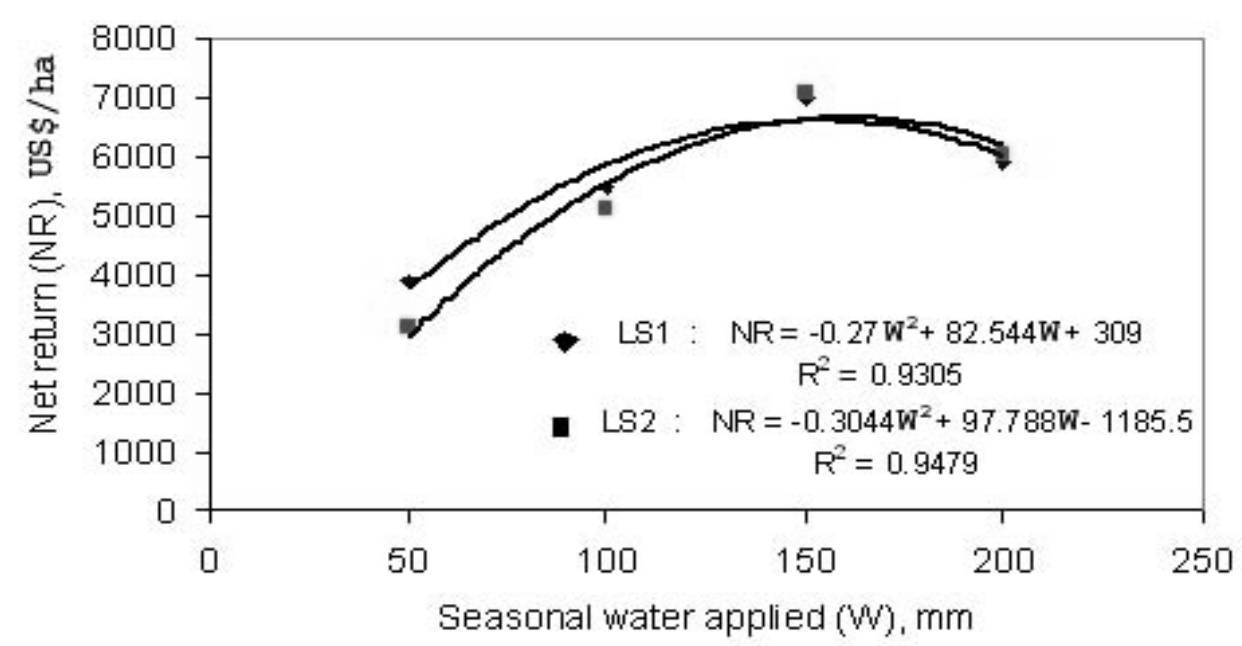

Fig. 3:Relationship between seasonal water applied and net return of Broccoli for $0.5 \mathrm{~m}$ and $1.0 \mathrm{~m}$ lateral spacing

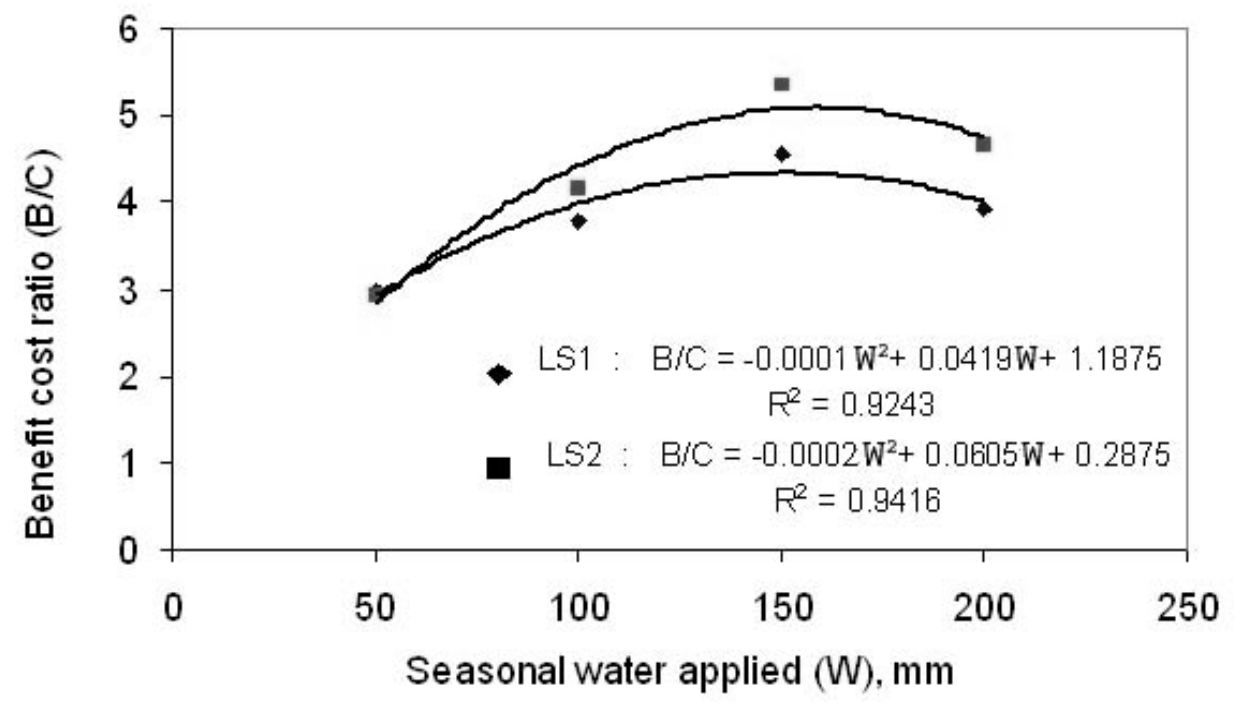

Fig. 4:Relationship between seasonal water applied and benefit cost ratio of Broccoli for $0.5 \mathrm{~m}$ and $1.0 \mathrm{~m}$ lateral spacing

118 Journal of Science and Technology, Volume 27 no. 2, August, 2007 
increased with an increase in seasonal water applied and gross return for $0.5 \mathrm{~m}$ and $1.0 \mathrm{~m}$ lateral spacing respectively and thereafter it tended to decline (Fig. 1). The relationship between seasonal water applied for $0.5 \mathrm{~m}$ and $1.0 \mathrm{~m}$ lateral spacing ranged from 5827 to 8986 and 4691 to 8723 US\$ / ha respectively. The seasonal water applied and gross return for $0.5 \mathrm{~m}\left(\mathrm{R}^{2}=0.9327\right)$ and $1.0 \mathrm{~m}\left(\mathrm{R}^{2}=0.9492\right)$ lateral spacing exhibited a strong quadratic relationship. The gross return of broccoli increased with an increase in seasonal water applied for $0.5 \mathrm{~m}$ and $1.0 \mathrm{~m}$ lateral spacing respectively and thereafter, gross return tended to decline (Fig. 2). The relationship between seasonal water applied and net return of broccoli for $0.5 \mathrm{~m}$ and $1.0 \mathrm{~m}$ lateral spacing ranged from 3893 to $7011 \mathrm{US} \$$ /ha and 3093 to $7084 \mathrm{US} \$ /$ ha, respectively. The seasonal water applied and net return for $0.5 \mathrm{~m}\left(\mathrm{R}^{2}=0.9305\right)$ and $1.0 \mathrm{~m}\left(\mathrm{R}^{2}=\right.$ 0.9479 ) lateral spacing exhibited strong quadratic relationship. The net return of broccoli increased with an increase in seasonal water applied for $0.5 \mathrm{~m}$ and $1.0 \mathrm{~m}$ lateral spacing respectively and thereafter gross return tended to decline (Fig. 3). The relationship between seasonal water applied and benefit cost ratio for $0.5 \mathrm{~m}$ and $1.0 \mathrm{~m}$ lateral spacing ranged from 3.00 to 4.54 and $2.93-5.35$ respectively. The seasonal water applied and benefit cost ratio for $0.5 \mathrm{~m}\left(\mathrm{R}^{2}=0.9243\right)$ and $1.0 \mathrm{~m}\left(\mathrm{R}^{2}=0.9416\right)$ lateral spacing exhibited strong quadratic relationship. The benefit cost ratio of broccoli increased with an increase in seasonal water applied for $0.5 \mathrm{~m}$ and $1.0 \mathrm{~m}$ lateral spacing respectively and thereafter it tended to decline (Fig. 4). The fitted regression model relating pan evaporation replenishment and benefit cost ratio under different irrigation levels and lateral spacing could be used for irrigation scheduling for optimum economic returns.

Inspite of some variation, the overall results showed strong quadratic relationship between seasonal water applied/irrigation levels and gross return, net return and benefit cost ratio for broccoli under varying lateral spacing. Tiwari and Reddy (1997) reported similar results for banana.

\section{CONCLUSION}

The experimental results for both years showed that irrigation with $150 \%$ evaporation replenishment resulted in the highest marketable yield of winter broccoli. Irrigation at 50\% pan evaporation replenishment produced higher irrigation production efficiency. Irrigation with $200 \%$ pan evaporation replenishment reduced the irrigation production efficiency because it increased the seasonal water application considerably without a significant improvement in marketable yield. The net return for broccoli increased sharply from 50 to $150 \%$ pan evaporation replenishment for $0.5 \mathrm{~m}$ and $1.0 \mathrm{~m}$ lateral spacing. In both year's seasonal water applied and marketable yield of broccoli for $0.5 \mathrm{~m}$ and $1.0 \mathrm{~m}$ lateral spacing exhibited strong quadratic relationship. Irrigation water production functions developed in the present investigations can be used for allocating water within and between the above mentioned crops, comparing irrigation production efficiency and economic analysis. Finally the overall results clearly suggest that in order to obtain an optimum yield, irrigation production efficiency and net return of broccoli in the northern plain of India, crops during the winter season should be irrigated at $150 \%$ of pan evaporation replenishment and the lateral spacing $1.0 \mathrm{~m}$ gave the highest net return for broccoli. Furthermore, an irrigation management approach using pan evaporation data is simple and can be adopted easily by farmers. Inspite of the high initial investment, drip irrigation for vegetable production in Allahabad region, India is highly profitable because of the high market price of the produce. Clogging of the drippers is the main concern, but it can be minimised by using appropriate fitters and flushing out the main, sub main and lateral lines regularly.

\section{ACKNOWLEDGEMENTS}

The authors are grateful to Allahabad Agricultural Institute-Deemed University, Allahabad, India, for providing financial support to carry out the study. 


\section{REFERENCES}

Camp, C. R., Baner, P. J., Hunt, P. G. (1997). Subsurface drip irrigation lateral spacing and management for cotton in the south-eastern coastal plain. Trans ASAE 40 (4) : 993 999

Devitt, D. A., Miller, W. W. (1988). Subsurface drip irrigation of Bermuda grass with saline water. Applied Agric. Res. 3 (3) : 133 - 143

Fekadu, Y., Teshome. T.(1998). Effect of drip and furrow irrigation and plant spacing on yield of tomato at Dire Dawa, Ethiopia. Agric Water manage 35 : $201-207$

Hanson, B. R., Schwankl, L. J., Schulbach, K. F., Pettygrove, G. S.(1997). A comparison of furrow, surface drip and subsurface drip irrigation on lettuce yield and applied water. Agric Water manage $33: 139$ - 157

Hiller, E. A., Howell, T. A.(1973). Grain Sorghum response to trickle and subsurface irrigation. Transactions of the ASAE 16 (4) : $799-803$

Imtiyaz, M., Mgadla, N. P., Chepete, B., Manase, S.K.(2000d). Marketable yield, water use efficiency and economic return of cabbage, carrot and onion as influenced by irrigation schedules. In: Proceedings of International Agricultural Engineering Conference, Asian Institute of Technology, Bangkok pp 321 328

Imtiyaz, M., Mgadla, N. P., Manase, S. K. (2000c). Response of green mealies to water levels under sprinkler and drip irrigation. In : Proceedings of International Agricultural Engineering Conference, Asian Institute of Technology, Bangkok pp $343-350$

Imtiyaz, M. ,Mgadla, N. P., Manase, S. K. (2000b). Response of six vegetable crops to irrigation schedules. Agric Watermanage $45: 331-342$

Imtiyaz, M. ,Mgadla, N. P., Manase, S. K., Chendo, K., Mothobi, E. O. (2000a). Yield and economic return of vegetable crops under variable irrigation. Irrig. Sci. 19 : pp 87 $-93$

Imtiyaz, M., Shiromani, S.(1990).Berseem production as influenced by limited irrigation. Proceedings of the International Agricultural Engineering Conference and Exhibition, Bangkok, Vol. 3 pp $807-814$

James, L. D., Lee R. R.(1971). Economic of water resources planning. McGraw Hill, New Delhi, p 20

Jensen, M. E., Rob, D. C. N., Franzoy, C.E. (1970). Scheduling irrigation using climatic crop soil data. J. Irrig. Drain $96: 25$ - 38

Lamm, F. R., Manges, H. E., Stone, L. R., Khan, A. H., Rogers, D. H.(1995). Water requirement of subsurface drip irrigated corn on Northwest Kansas. Trans ASAE 38 (2) : 441 $-448$

Mahdi., Kaisi, A. L., Berrada, A., Stack, M. (1977). Evaluation of Irrigation scheduling program and spring wheat yield response in southwestern Colorado. Agricultural Water management $34: 137-148$

Misra, R. D., Pant, P.C. (1981). Criteria for scheduling irrigation of wheat. Exp. Agric. $17: 157-162$

Phene, C.J.,Beale, O.W. (1976). High frequency irrigation of water nutrient management in humid regions. Soil Sci Soc. Am. J. 40 (3)

Prihar, S. S., Gajri, P. R., Narang, R. S.(1974). Scheduling of irrigation to wheat using pan evaporation. Indian J Agric. Sci. $44: 567-$ 571

Pruitt, W. O., Fereres, E.,martin, P. E., Singh, H., Herdersen, D. W., Hagan, R.M., Tarantino, E., Chandio, B.(1984).microclimate, evaportranspiration and water use efficiency for drip and furrow irrigated tomatoes. Trans ASAE 489 - 493

Srivastava, P. K., Parikh, M. M., Swani, N. G., Raman, S.(1994). Effect of irrigation and

120 Journal of Science and Technology, Volume 27 no. 2, August, 2007 
mulching on tomato yield. Agric Water manage $25: 179-184$

Singh, B. P.(1987). Effect of irrigation on the growth and yield of Okra. Hort Sci $22: 879$ $-880$

Singh, P. N., Mohan, S. C.(1994). Water use and yield response of sugarcane under different irrigation schedules and nitrogen levels in a subtropical region. Agric Water manage 26 : $253-264$

Singh, S., Ram,M., Ram, D., Sharma, S., Singh, D. V.(1997). Water requirement and productivity of palmarosa on sandy loam soil under subtropical climate. Agric Watermanage 35 : $1-10$
Steele, D. D., Gregor, B. L., Shae, J. B.(1997). Irrigation scheduling methods for popcorn in the Northern Great plains. ASAE 40 (1) : $149-155$

Theodor, W. S.(1980). Comparison of Sprinkler, trickles, subsurface and furrow irrigationmethods for row crops. Agron. J. 72 : $701-$ 704

Wanjura, D. F., Upehurch, D. R.,Mahan, J. R. (1990). Evaluating decision criteria for irrigation scheduling in cotton. Trans ASAE $33: 512-518$ 